\title{
Monitoring of Official Degree Qualifications: The Key Role of Academic Quality Assurance Systems (AQAS)*
}

\author{
El proceso de seguimiento de los títulos oficiales: El papel \\ "clave" de los Sistemas de Garantía de Calidad
}

Recibido: abril 29 de 2011 | Revisado: marzo 12 de 2012 | Aceptado: marzo 30 de 2012

\author{
CARMen Pozo MuÑoz ** \\ BlanCA BRETONES NieTO *** \\ Universidad de Almería, España \\ María José MARTOS MÉNDEZ ***** \\ Universidad de Málaga, España \\ ENRIQUE AlONSO MORILlEJO****** \\ Universidad de Almería, España \\ María Pilar García RodríGUeZ ******* \\ Universidad de Huelva, España
}

SICI: 1657-9267(201303)12:1<209:MODCTK>2.0.TX;2-7

Para citar este artículo: Pozo, C., Bretones, B., Martos, M. J., Alonso, E. \& García, M. P. (2013). Monitoring of official degree qualifications: The key role of Academic Quality Assurance Systems (AQAS). Universitas Psychologica, 12(1), 209-220.

* This article refers to a comprehensive review of the legal and evaluative procedures developed in relation to the construction and implementation of Academic Quality Assurance Systems (AQAS) offered under the European Higher Education Area. Thus, this study reflects the actions taken at European, Spanish and in the context of the University of Almeria.

** Doctora en Psicología por la Universidad Autónoma de Madrid. Profesora Titular de la Universidad de Almería.E-mail: cpozo@ual.es

**** Licenciada en Psicología por la Universidad de Almería.E-mail: bbretones@ual.es

****** Doctora en Psicología por la Universidad de Almería. Profesora Ayudante Doctora de la Universidad de Málaga.E-mail: mjmartos@uma.es

******* Doctor en Psicología por la Universidad de Almería. Profesor Titular de la Universidad de Almería. E-mail: ealonso@ual.es

********* Doctora en Psicopedagogía. Profesora Contratada Doctora de la Universidad de Huelva. E-mail: mpgarcia@uhu.es
A B S T R A C T

The purpose of this article is focused on the development of a protocol designed to facilitate the monitoring process of the official degrees of a Spanish university. In response to the criteria and guidelines established in the Royal Decree 1393/2007, this proposal seeks to make available to the focus groups a useful and flexible tool, tailored to the different existing regulations, which assesses progress in the development of the curriculum, ensures the effective implementation of the degrees, and publishes the information available, relevant and appropriate. It also helps to identify weaknesses, potential improvements and best practices for dissemination. All this, with the ultimate aim of assuring the accreditation of Official Degrees. The monitoring protocol articulates the assessment, as a Check-List, in fulfillment of an annual series of indicators set out in the Academic Quality Assurance Systems (AQAS) included in the Proceedings of Degrees. Finally, the monitoring of new degrees comes up as a result of adaptation to the requirements of the European Higher Education Area.

Key words authors

European Space for Higher Education, monitoring of degrees, Quality Assurance

Systems.

Key words plus

Academic Quality, Educational Policy, Spain

\section{RESUMEN}

El propósito de este artículo se centra en el desarrollo de un protocolo diseñado para facilitar el proceso de seguimiento de las titulaciones oficiales en las Universidades Españolas. En respuesta a los criterios y directrices establecidos en el Real Decreto 1393/2007, la presente propuesta tiene por objeto poner a disposición de los grupos de interés una herramienta útil y flexible, adaptada a las diferentes regulaciones existentes, que evalúa el progreso en el desarrollo del plan de estudios, asegura la aplicación efectiva de los grados, y publica la información disponible, relevante y apropiada. También ayuda a identificar los puntos débiles, las posibles mejoras y las prácticas más adecuadas para su difusión. Todo esto, con el fin último de garantizar la acreditación de los Títulos Oficiales. El protocolo de seguimiento articula la evaluación, así como una lista de control, en cumplimiento de una serie 
de indicadores establecidos en los Sistemas de Garantía de Calidad (SGC) incluidos en los Procedimientos de Grado. Por último, el seguimiento de los nuevos Títulos de Grado surge como resultado de la adaptación a los requerimientos del Espacio Europeo de Educación Superior.

Palabras clave autores

Espacio Europeo de Educación Superior, Seguimiento de Títulos, Sistemas de Aseguramiento de la Calidad.

Palabras clave descriptores

Calidad académica, políticas en educación, España.

\section{Introduction}

Since May 25 ${ }^{\text {th }}$ 1998, when the Ministries of Education of France, Germany, Italy and the United Kingdom signed the Sorbonne Declaration encouraging the development of a European Space for Higher Education (ESHE), the changes occurred in the field of university education which meant the adoption of new models that have a direct impact on the management, structures, requirements and expectations of society, students, teachers and the university community in general (Red Iberoamericana para la Acreditación de la Calidad de la Educación Superior [RIACES], 2007). The Communication published by the Berlin Conference of Higher Education Ministers (2003) represented an awareness of the need to develop comparable criteria and methodologies to establish a Higher Education system intended to guarantee quality (Dahlgren, Fejes, Abrandt-Dahlgren \& Trowald, 2009; Muñoz, 2009).

The Construction of the ESHE has brought a change in the university education model (Roxa \& Martensson, 2008) now focused on the students' learning and oriented at developing competencies which will enable them to adapt to an ever changing work market, which demands that they keep abreast professionally of the latest developments throughout their lives. In this way, the educational mobility between European universities and employability has been defined as the result of a Higher Education of Quality (Akhtar, Riaz \& Topping, 2009; Dickie \& Jay, 2010; Harvey \& Kamvounias, 2008; Rentería-Pérez \& Malvezzi, 2008; StØren \& Aamodt, 2010; Woodhouse, 2006).

Furthermore the adaptation of University Degrees to the ESHE framework requires an im- provement in the quality of university activities, introducing systematic internal and external assessment mechanisms that produce direct and indirect impacts in the style of university management and in creating new academic culture (Calderón \& Escalera, 2008; Haapakorpi, 2011).

The mentioned convergence process, intends to establish comparable criteria and methodologies amongst the different Higher Education institutions, so that some minimal requirements of quality of teaching can be guaranteed (Alzate-Medina, 2008; European Commission. Education \& Training, 2009). This is being made possible thanks to the assumption of the member countries of some common recommendations on the matter of quality expressed by the European Association for Quality Assurance in Higher Education (ENQA), amongst which we find the necessary inclusion of Quality Assurance Systems in the various training offers (QAS) which will ensure the suitability of the education process. All this will lead, not only to better training for students but also to results which will meet the demands of society.

Quality Assurance Systems have produced a radical change in the way of understanding teaching, management, and in general, every process involved in Higher Education. A Quality Assurance System (QAS) can be defined as a set of interlinked elements to manage in a planned way the quality of courses, through seeking the satisfaction of its clients and/or stakeholders, and focused on the continuous improvement of the teaching, research, management and services on offer (Hodgson \& Whalley, 2007). A QAS reflects the commitment to Degrees in order to guarantee the quality of teaching, to disseminate the results and to become involved in constant improvement, through formal mechanisms for the approval, control, periodic revision and improvement.

\section{The European Regulations Framework}

The Bologna process has, therefore, served as an important stimulus in the development of systems to ensure the quality of Higher Education, and this can be seen in the different Ministries of Education 
biannual Conferences which have been taking place over the last decade, since 1998, with the Declaration of the Sorbonne, until 2009 with the Treaty of Louvain (European Commission. Education, Audiovisual \& Culture Executive Agency [EACEA], 2009). In each of them, the quality assurance has been one of the priorities for discussion, either through recommendations to promote European cooperation with regard to quality assurance (European Higher Education Area. Declaration of Bologna, 1999; Neave, 2003) or prioritising the development of systems to ensure quality on institutional, national and European levels (European Higher Education Area, 2003), or furthermore, establishing standards and guidelines for quality assurance in accordance with the proposal of the ENQA report (European Higher Education Area, 2005), accepting the creation of the European Quality Assurance Register -EQAR- (European Higher Education Area, 2007).

The Guidelines for Quality Assurance in the ESHE, approved at the Bergen meeting 2005, recommend quality assurance as one of the rules for the performance of universities. Moreover, this set of criteria and guidelines has been the first step towards establishing values and good practices shared by the member countries of the European Union. With regard to universities, ENQA, like responsible entity in quality area in Europe, collects criteria and guidelines focusing on policy and procedures to ensure quality, control and periodical revision of curricula and Degrees, teaching staff quality assurance, etc. All these through the transparency in the field of quality assurance within the context of the political cooperation in the European university (Ala-Vähälä \& Saarinen, 2009).

In a parallel way, in Spain, the Ministry of Education (MEC) presented a document in 2003 about the integration of the Spanish University System in the ESHE, which stated the need to promote European cooperation in order to ensure university quality through the development of networks, joint projects and specific support organisations (Ministerio de Educación, Cultura y Deporte, 2003). Thus, the document "Guidelines for the preparation of first and second Degrees" published by the MEC in 2006, states amongst its general principles the need to introduce a Quality Guarantee System as one of the necessary elements for future Degree proposals.

Royal Decree 1393/2007 (and Royal Decree 861/2010), which establishes the Ordinance of Official University Education in Spain, includes the guidelines, conditions and procedure for assessment that the University Curricula should pass before they can be implemented according to the European model. In accordance with the abovementioned Royal Decree, official degrees will be assessed by the National Agency for Quality Assessment and Accreditation (ANECA) or by the appropriate Autonomous Agencies.

The establishment of a Quality Assurance System (QAS) appears in Spanish legislation as an obligatory condition for the verification and accreditation process of Degrees. The QAS for an M.A. Degree should include five criteria: 1 ) identification of those responsible for the QAS Curricula; 2) procedures to assess and improve the quality of teaching; 3) systems to guarantee the quality of external practices and mobility programmes; 4) procedures for the analysis of work placements for graduates and satisfaction with the training; and 5) satisfaction analysis systems for the different groups involved, suggestions and claims, as well as specific criteria in the case of a Degree becoming extinct.

Furthermore, it is necessary to have mechanisms that guarantee openness and transparency in the information available to students, to Administrative Staff and Services, Teachers, future students and society in general.

In short, the actions and procedures contained in the Quality Assurance System for Degrees from the Spanish Universities are in accordance with the "Criteria and Guidelines for Quality Assurance in the European Space for Higher Education" prepared by the -ENQA- and allow the combination of assessment and supervision, carried out by those responsible for Degrees, Education Centres and by the University as a whole. 


\section{The Evaluation of Degrees in Spain}

In Spain, the assessment of University education is starting to have consequences, as the authorisation for official Degrees to be taught at universities depends on it, and it has progressed from an assessment which is basically focused on what to improve to an assessment which seeks to provide keys to improve every aspect, while respecting the autonomy of universities.

Universities themselves have prepared proposals for official Degrees, complying with rules established on a national level. Once the proposals have been presented, they have had to undergo an assessment (verification) process, and in a future phase, they will be subjected to accreditation (Egido, Gálvez \& Haug, 2006), for which it will be necessary to establish a monitoring procedure which will allow the detection of deficiencies in the implementation of Curricula, so that they can be corrected for future accreditation.

Universities have also designed Quality Assurance Systems for Degrees, in order to ensure their quality and improve information for the public about the characteristics of the university offers.

Up to February 2010, 1677 Degree assessments have been carried out in Spain, of which 1591 have obtained a favourable report on the part of the ANECA. As to official M.A. Degrees, 1936 have been evaluated and 92 have not passed this process (González-Vega, 2010). Once these degrees are put into practice, the monitoring process becomes an essential element and its repercussions are vital, due to the fact, among others, which is aimed at solving the educational needs of society, as well as justifying and giving visibility and credibility to the Spanish University System and to the change and improvement process (Fernández, 2010).

This new scenario has presented a new challenge for the university system agents: the development of mechanisms for the proper implementation of Degrees, taking as their central axis the QAS designed.

\section{Quality Assurance Systems-in Spain: The case of the University of Almería}

In order to guide and assist the task of those responsible for the Education Centres in the development of their Quality Assurance Systems the Quality Unit of the University of Almería (UAL), starting from the national and autonomous regulations, has designed a Manual for the Design of Quality Assurance Systems, consisting of a series of procedures and associated tools. With this Manual, they seek to contribute to 1) positively improve the verification of the Quality Assurance System design; and 2) establishing a systematic process to continually improve all the aspects of the Curriculum. This manual was made available to all those in charge of designing Quality Assurance Systems

The Manual is structured as follows:

Those responsible for the design, implementation and follow-up of the QAS (seehttp://cms.ual.es/idc/groups/public@serve/@ ucalidad/documents/documento/unidad calidad.pdf)

They are called "Quality Assurance Units for Degrees" (QAUD) (UGCT) and their purpose is to adapt, set in motion and carry out the follow-up of Quality Assurance Systems for the appropriate Degree. Their main aim is to adapt the procedures and tools designed to the specific context of each Degree, using a highly thorough training process beforehand and with the guidance of the Quality Unit of the University of Almería.

On the other hand, the Quality Unit is in charge of coordinating the Quality Assurance Units for all University Degrees, advising these Units about the design of their Quality Assurance Systems and undertaking the training of their members.

\section{Procedures}

Each procedure (see in picture 1 the procedures included in the Quality Assurance Systems has a reference code (for example P-1), which is linked, in its case, to a series of tools or instruments to collect the information presented in an Annex: 
(http://cms.ual.es/idc/groups/public/@serv/@ ucalidad/documents/documento/scgt.grado.pdf)

For each procedure there is a record model in which the code and the title of the procedure appears, as well as its objective, its legal reference and assessment reference, the system by which it was collected and the information analysis used, the system of proposals to improve and its timetable, as well as a section about "specific aspects" for any other consideration to be added.

TABLE 1.

QAS Degree Procedures of the University of Almería

P-1. Procedure for the assessment and improvement of the quality of teaching and teachers

P-2. Procedure for the assessment of External Practices

P-3. Procedure for the analysis of Mobility

P-4. Procedure to assess the work placements of graduates and their satisfaction with the training received.

P-5 Procedure for the assessment of the overall satisfaction with the Degree

P-6. Procedure for suggestions and claims

P.7. Procedure for the dissemination of the Degree

P-8. Specific criteria and procedures used when the Degree becomes extinct.

Source: University of Almería (2010).

\section{Tools}

The tools associated with each of the procedures are a group of instruments that seeks to unify the process of collecting information on Degrees offered by the University of Almería. Thus, the results obtained refer both to the satisfaction of the different agents involved (for example, the "opinion survey carried out among students on the teaching of their lecturers", which corresponds to the procedure for the assessment and improvement of the quality of teaching and teachers; "the survey for the evaluation of external tutors" in the case of the procedure for the assessment of external practices, among others), and to potential incidents detected (for example, through an incident report model related to teaching or a box of suggestions and claims with regard to the elements of a Degree).
In short, at the University of Almería the work is being carried out with the purpose of turning the Quality Assurance Systems of the new Degrees into a vehicle which will guarantee the quality of teaching, making all the agents involved (students, administrative staff, teaching staff) participate in this process emphasising the relevance of disseminating the results, always with a clear commitment to constant improvement.

\section{Degree monitoring Procedure}

Once new degrees have been designed and implemented in Spain, the next step is to adopt follow-up or monitoring procedures, which will guarantee the quality of the Curricula. This process will be conditioned by the way in which the Curricula are established, and QAS's are the tool that provides information about which improvements are required throughout the implementation of a Curriculum.

RD 861/2010 stresses the role of a Degree monitoring for its subsequent accreditation. This process seeks the right implementation of the teaching offered, detecting the main barriers and difficulties, and verifying that the requirements established in the Quality Assurance Systems are truly being put into practice in the way they were designed. Likewise, the improvement proposals presented will allow the identification of good practice, as well as the availability of formal mechanisms for the control and revision of Degrees (Red Española de Agencias de Calidad Universitaria [REACU-Spanish Network of University Quality Assurance], 2010).

The new University model implies a redefinition of the aims pursued, a revision of the academic offers and the renewal of teaching models, evaluating the methodology of teaching and providing students with strategies that promote lifelong learning (Chalmers \& Fuller, 1999). The Quality Assurance Systems will allow the management of the different elements that compose Curricula with the aim of their constant improvement.

Thus, currently the universities are working on designing monitoring protocols which will facilitate the decision making with regard to the characteristics of the teaching they offer. All this bearing in 
mind the multiplicity of the criteria required (Agencia Nacional de Evaluación de la Calidad y Acreditación [ANECA], 2007; Consejo de Universidades \& Conferencia General de Política Universitaria, 2010; ENQA, 2005; Ministerio de Educación, Cultura y Deporte, 2003; REACU, 2010; Boletín Oficial del Estado, 2007) the timetable for carrying out the actions stated in the Quality Assurance Systems and the various agents involved (internal and external).

On a national level it is necessary to analyse at least the following aspects of a Degree (Consejo de Universidades, 2010, p. 5):

1 The appropriate and relevant information for students and society in general, which all Universities should make public about each of their Degrees. This public information should be updated and objective and should at least contain:

- The most relevant characteristics of the Degree report.

- The operational deployment of the Curriculum for each year, identifying the specific teaching plan, the teaching staff and specific guidelines for the work and the assessment of students.

- 2 The information about a nucleus of minimal indicators that will facilitate the preparation of the annual follow-up report. These indicators are performance rate, drop out rate and graduation rate with regard to the Degree.

- 3 The information derived from the evaluation of the implementation of the Quality Assurance System, with the identification of problems detected and decisions adopted to resolve them.

- 4 The actions carried out in light of the recommendations established in both the verification reports and in the subsequent follow-up reports.

- A monitoring process should be based on the following criteria (Consejo de Universidades, 2010, pp. 6-7):

- Transparency and accessibility.

- Usefulness.

- Record of achievements.

- Internal commitment of the Centre/Institution.

- Reliance on the Quality Assurance System of the Degree.

- Guidelines for improvement.

\section{Proposal for a Monitoring Protocol for QAS's in a Spanish University}

In the next pages a proposal developed by the Quality Unit of the University of Almería is presented, in order to carry out the follow-up process of the already evaluated and implemented Degrees starting from the academic year 2009/10. This proposal is materialized in a protocol designed to guarantee that Graduate and M.A. Degrees implemented are being developed as planned, and respond to the basic quality criteria required.

The Monitoring Protocol presented is consistent with the work carried out by different Agencies with the current regulations to date. Among the aims of the follow-up, some are listed below (Consejo de Universidades, 2010; University of Almería, 2010):

1. To ensure effective teaching.

2. To ensure that the recommendations of the Degree Evaluation Committee are implemented.

3. To guarantee the public availability of information for the different agents of the university system.

4. To detect the possible deficiencies in the development of teaching and analysing the actions carried out to correct them.

5. To contribute in the improvement proposals during the implementation of the Degree.

6. To identify the good practice for dissemination throughout the Spanish university system.

7. To reveal the progress made in developing the Quality Assurance System.

8. To obtain relevant information to analyse globally the degree of adaptation of the Spanish university system to the ESHE context.

The purpose of this proposal is to make available to the various groups involved a useful, systematic and flexible tool that will ensure the effective implementation of Degrees, the availability to the public of pertinent and relevant information, the detection of potential deviations, the contribution of recommendations and/or suggestions for im- 
provement and the identification of good practice for subsequent dissemination.

In general, the preparation of procedures for monitoring the new Degrees should provide guidance at least about the following:

- What should be evaluated: dimensions, variables and indicators.

- How information should be collected: sources, tools and those in charge of their application.

- When action should be taken and,

- Who should be responsible for action.

\section{What Should Be Evaluated?}

The first task is to analyse the information from the procedures of the Quality Assurance System of the new Degrees of the University of Almería and to set in motion the follow-up process, establishing dimensions to group the variables to be assessed, translated into specific indicators. These dimensions can be concentrated in the following:

Dimension 0: Supply and demand of university places and enrollment

Dimension I: Information available to the public

Dimension II: The quality of teaching and the assessment of learning

Dimension III: The quality of External Practices

Dimension IV: The quality of Mobility Programmes

Dimension V: The Work Placement of Graduates and their satisfaction with the training received

Dimension VI: Global satisfaction with the Degree

Dimension VII: Suggestions and/or claims

\section{How Should Information Be Collected?}

Secondly, with regard to ways of obtaining information, there is a great diversity of sources involved in the correct implementation of each Degree, which are in turn the groups involved.

The Quality Assurance Systems have specific instruments to analyse each one of the procedures that compose them. Thus, it is the Quality
Unit itself that is in charge of supplying information to those responsible for the application of the pertinent tools through the various stages of the implementation of a Degree. To facilitate this task, instruments have been developed in an online format, which make the process of collecting information less tedious.

Likewise, the Quality Unit has designed a checklist and a Degree report to make the followup task of their Coordinators easier.

\section{Check-List}

To facilitate the follow-up process of the (QASD's), the Quality Unit has developed a check-list which will be adhered to those Responsible for Degrees through a series of established stages, from the moment before the implementation to six years after the start (or four years in the case of M:A's).

This checklist presents a dichotomous response format (Yes/No), besides including open items in which it is possible to incorporate clarifications or Web links to contrast the information stated.

The results of the application of this tool will provide useful information that will allow those responsible for curricula to make decisions about the way in which the Curricula work. Although the correct implementation of Degrees is a key element for their success, it is the Quality Assurance System, which will provide information about the changes that are necessary for the constant improvement of Curricula.

After the checklist, the Quality Unit of the University of Almería will carry out a verification (through the revision of the Degree Web Pages) to ensure that the criteria established are being implemented, thus being able to amend possible deficiencies for a subsequent external verification to be carried out by the AGAE. This revision will be done selecting annually and randomly some of the Degrees (Graduate and M.A.) implemented at the University of Almería.

\section{Report for the Follow-up of Degrees}

Likewise, to facilitate the preparation of the annual report for each Degree, the Quality Unit has 
devised a report model, which is identical for all the Graduate Degrees at UAL. This will be implemented annually by the person responsible for the Degree in question, in close collaboration with its Quality Assurance Unit.

\section{When Is The Information Collected?}

The timetable of the information collection process by the collectives involved in the Degree, is determined by its implementation. Thus, before the implementation of Degrees and at the start of each academic year, those mechanisms that ensure the correct dissemination of their characteristics will be available, and a suggestions and claims system will also be in place. On the other hand, throughout the implementation of the Curriculum, results on the quality of teaching will be collected. Likewise, from the fourth year onwards, the quality of Mobility Programmes should also be assessed in terms of their characteristics and suggestions and claims register. During the fourth year, the characteristics of the External Practices Programme will be available, as well as the incident reports related to it, to name a few.

\section{Who Provides and/or Collects the Information?}

In the area of education policies, contrary to what happens nowadays, the impact of Higher Education on the various groups involved has traditionally gone unnoticed (Tandberg, 2010). However, the twenty-first century university is known for its concern and efforts to improve the management of teaching from the perspective of different actors that make up the university community (Gray \& Radloff, 2006).

In the QAS context, during the implementation of new Degrees, various agents intervene who to a greater or lesser extent, participate in or are in some way responsible for the assessment and follow-up procedure presented in this document. Thus, most of the information comes from the Degree Coordinators or from other support staff from the Centre linked to quality management, as well as from external agents (practice tutors, quality experts required by the UGCT's (QAUD's) at certain times during the implementation of the Degree, etc.) and of the institution databases (Quality Unit, Vice-chancellor's Office for Internationalisation and Development Cooperation, University Employment Service...). In the same way, the involvement of students, teachers, Administrative and Service Staff of the University are also necessary.

To be specific, the main agents involved are listed below:

a) The Degree Follow-up Committee

The Degree Follow-up Committee of the UAL consists of the main representatives of the University and provides a framework for the proper functioning of the new Curriculum implemented at the University. Thus, their functions are aimed at a constant revision of the implementation process of Official Degrees; proposing pertinent and duly justified modifications, suggesting proposals for improvement which will guarantee the future accreditation of the teaching carried out within the context of the University of Almería.

b) The Quality Unit of the University of Almería

The Quality Unit is in charge of the design and revision of the Quality Assurance Systems for the new Graduate and M.A. Degrees taught at the University of Almería. It also carries out the following tasks:

Coordination of dissemination and consultancy functions, addressed at the various groups involved in (Degree Coordinators, UGCT, UGCR, etc.) and linked to the follow-up of Curricula.

Design and implementation of procedures and tools (Report models, information collection techniques referred to the procedures that compose the Quality Assurance Systems for the new Graduate and M.A. degrees of the UAL, check-list, etc.) to provide guidance for the different agents involved in actions related to Degree follow-up.

Collection, codification and analysis of data obtained through different tools.

Preparation of reports of the results obtained through the Quality Assurance Systems for Degrees offered by UAL. 
Dealing with recommendations and/or suggestions from the different assessment agencies in this case (ANECA and AGAE) for the verification and follow-up of the new Graduate and M.A. Degrees for their subsequent accreditation.

c) Degree Coordinators

Their work is based on coordinating activities collected in the Curriculum and confirming that the requirements established in the QAS's are actually being put into practice during the Degree implementation process. In this respect, the cohesion and joint work of the Quality Assurance Units for Graduate Degrees is crucial.

d) The Quality Assurance Unit for Degrees (UGCT) (QAUD)

Its mission is to provide quality indicators that will make the Graduate Degree more and more satisfactory and attractive for all the interested parties (students, teachers, administrative staff, employers and society in general) so that demand will increase.

\section{Discussion}

The Quality Assurance Systems included in the new Degrees will allow the supervision of teaching practices and will be accountable to society for their quality (Aelterman, 2006). This has meant an important leap in the offer of quality Curricula in response to the real needs of students and of society in general (Pozo-Muñoz, Giménez \& Bretones, 2009).

From the multidimensionality of the concept of "educational excellence" (Elton, 1998), stand out as important goals to work towards continuous improvement, the use of available information for policy decisions (to advance best practices is essential to ensure quality and comparability), accountability and transparency of processes (Brink, 2010; Rozsnyai, 2010).

Along these lines, it is possible to identify good practice to be disseminated in the Spanish University System from the recommendations for improvement introduced throughout the implementation of Curricula. However, the follow-up must not be a duplication of already existing revision processes, but the procedures contemplated in the Quality
Assurance System should be applied to Degrees for their continuous improvement.

The idea of unifying the evaluation processes of the titles in the universities (up accreditation) requires an institutional commitment and to establish a quality culture shared by all members of the university community (Cheng, 2010).Thus, as a general rule, the follow-up process should show the progress made in the development of the Quality Assurance System for Degrees, both with regard to the implementation of the Curriculum and with regard to proposals for its ongoing improvement.

Equally, evaluating quality should be used to create projects that will show common improvements that will have an impact on the evolution of Degrees, Centres and Universities as a whole (Lundquist, 1998; Pozo et al., 2009); thus, the demand for the social responsibility of Universities to the society that supports them is met (O'Donovan, Price \& Rust, 2004).

In short, the new University model involves a redefinition of its objectives, reflecting the new social demands, which requires more flexible and diversified structures that will favour interdisciplinarity, will encourage the participation of the different groups involved in education matters (Lédic, Rafajac \& Kvac, 1999; Malen, 2001), the review of the academic offer, the renovation of its teaching models, the strengthening of training and of the professional qualifications of teachers (CamargoEscobar \& Pardo-Adames, 2008; Fernández-Arata, 2008; Pill, 2005; Yinger \& Hendriks-Lee, 2000). All of this under the "umbrella" of Quality Assurance Systems that will allow the management of Curricula elements for their constant improvement.

The definition of these objectives should be public and shared by the whole university community, in order to reinforce account rendering and institutional communication with those around it.

It is evident that the current state of European universities demands greater autonomy, which can not be understood without a system of quality assurance and accountability process that will give them a significant social role (Crossouard, 2010). Thus, the demands for institutional accountability in higher education have increased (McAlpine \& 
Harris, 2002), so the evaluation systems and quality assurance play a key role in measuring the achievements attained, detecting the need to change and guaranteeing the quality of the service that the University provides to the society that supports it (Michavila \& Zamorano, 2008). In this sense, there are studies that show the level of satisfaction and optimism of principals and academics after the introduction of systems for quality assessment and its impact on the institutional area (Rosa, Tavares \& Amaral, 2006).

\section{References}

Alzate-Medina, G. M. (2008). Efectos de la acreditación en el mejoramiento de la calidad de los programas de Psicología de Colombia. Universitas Psychologica, 7(2), 425-439.

Aelterman, G. (2006). Sets of standars for external quality assurance agencies: A comparison. Quality in Higher Education, 12(3), 227-233.

Agencia Nacional de Evaluación de la Calidad y Acreditación. (2007). Programa VERIFICA: Protocolo de Evaluación para la verificación de títulos oficiales de Grado y Máster universitario. Available at http:// www.aneca.es/Programas/VERIFICA/Verificacion-de-Grado-y-Master

Akhtar, A., Riaz, H. \& Topping, J. (2009). Students' perception of university teaching behaviours. Teaching in Higher Education, 14(6), 631-647.

Ala-Vähälä, T. \& Saarinen, T. (2009). Building European level quality assurance structures: Views from within ENQA. Quality in Higher Education, 15(2), 89-103.

Brink, C. (2010). Quality and standards: Clarity, comparability and responsibility. Quality in Higher Education, 16(2), 139-152.

Calderón, C. \& Escalera, G. (2008). La evaluación de la docencia ante el reto del Espacio Europeo de Educación Superior (EEES). Educación XXI, 11, 237-256.

Camargo-Escobar, I. M \& Pardo-Adames, C. (2008). Competencias docentes de profesores de pregrado: diseño y validación de un instrumento de evaluación. Universitas Psychologica, 7(2), 441-455.
Chalmers, D. \& Fuller, R. F. (1999). Research and professional development in teaching learning strategies in context. International Journal for Academic Development, 4(1), 28-33.

Cheng, M. (2010). Audit cultures and quality assurance mechanisms in England: A study of their perceived impact in the work of academics. Teaching in Higher Education, 15(3), 259-271.

Consejo de Universidades \& Conferencia General de Política Universitaria. (2010). Protocolo para el seguimiento y la renovación de la acreditación de los títulos universitarios oficiales. Madrid: Comisión Universitaria para la Regulación del Seguimiento y Acreditación-CURSA.

Crossouard, B. (2010). Reforms to higher education assessment reporting: Opportunities and challenges. Teaching in Higher Education, 15(3), 247-258.

Dahlgren, L. O., Fejes, A., Abrandt-Dahlgren, M. \& Trowald, N. (2009). Grading Systems, features of assessment and students' approaches to learning. Teaching in Higher Education, 14(2), 185-194.

Dickie, C. \& Jay, L. (2010). Innovation in postgraduate teaching: Mixed methods to enhance learning and learning about learning. Higher Education Research \& Development, 29(1), 29-43.

Egido Gálvez, I. \& Haug, G. (2006). La acreditación como mecanismo de garantía de la calidad: tendencias en el Espacio Europeo de Educación Superior. Revista Española de Educación Comparada, 12, 81-112.

Elton, L. (1998). Dimensions of excellence in teaching. International Journal of Academic Development, 3(1), 3-11.

European Association for Quality Assurance in Higher Education. (2005). Standards and guidelines for quality assurance in the European Higher Education Area. Helsinki: Author.

European Commission. Education \& Training. (2009). The Bologna Process - Towards the European Higher Education Area. Bruselas: Eurydice/Eurostat. Available at http://ec.europa.eu/education/highereducation/doc1290_en.htm

European Commission. Education, Audiovisual \& Culture Executive Agency. EACEA P9 (2009). Key Data on Education in Europe. Bruselas: Eurydice/Eurostat. Available at http://eacea.ec.europa. 
eu/education/eurydice/documents/key_data_ series/105EN.pdf

European Higher Education Area. (1998, May). The Sorbonne Declaration of 25 May 1998. Joint declaration on the harmonization of the architecture of the European Higher Education System. The four Ministers in charge for France, Germany, Italy and the United Kingdom, Paris, France.

European Higher Education Area. (1999). The Bologna Declaration of 19 June 1999. Joint declaration of European Ministers of Education. Amsterdam: European Association for International Education. European Higher Education Area. (2003, September). Berlin Communiqué: Realising the European Higher Education Area. Conference of European Ministers responsible for Higher Education, Berlin, Germany.

European Higher Education Area. (2005, May). Bergen Communiqué: Achieving the goals. Conference of European Ministers responsible for Higher Education, Bergen, Norway.

European Higher Education Area. (2007, May). London Communiqué: Towards the European Higher Education Area: responding to the challenges of a globalized world. Conference of European Ministers responsible for Higher Education, London, England.

Fernández, Z. (Dir.). (2010). El Papel del Seguimiento y la Acreditación. Evaluación, Seguimiento y Acreditación de las enseñanzas universitarias: pasado, presente y futuro [Cursos de Verano]. Santander: Universidad Internacional Menéndez Pelayo.

Fernández-Arata, J. M. (2008). Desempeño docente y su relación con orientación a la meta, estrategias de aprendizaje y autoeficacia: un estudio con maestros de Primaria de Lima, Perú. Universitas Psychologica, 7(2), 385- 401.

González-Vega, L. (2010, May). Un primer análisis del proceso de verificación de las enseñanzas universitarias. Paper presented at Taller Los Sistemas de Calidad: la Verificación y el Seguimiento de los Nuevos Títulos, Cádiz, España.

Gray, K. \& Radloff, A. (2006). Quality management of academic development work: Implementation issues and challenges. International Journal for Academic Development, 11(2), 79-90.
Haapakorpi, A. (2011). Quality assurance processes in Finnish universities: Direct and indirect outcomes and organisational conditions. Quality in Higher Education, 17(1), 69-81.

Harvey, A. \& Kamvounias, P. (2008). Bridging the implementation gap: A teacher-as-learner approach to teaching and learning policy. Higher Education Research and Development, 27(1), 31-41.

Hodgson, K. \& Whalley, G. (2007). The effectiveness of a university's administration of its learning and teaching. Teaching in Higher Education, 12(2), 275-279.

Lédic, J., Rafajac, B. \& Kvac, V. (1999). Assessing the quality of university teaching in Croacia. Teaching in Higher Education, 4(2), 213-243.

Lundquist, R. (1998). Quality improvements of teaching and learning in higher education: A comparison with developments in industrial settings. Teaching in Higher Education, 3(1), 51-62.

Malen, B. (2001). Generating interest in interest groups. Educational Policy, 15(1), 168-186.

McAlpine, L. \& Harris, R. (2002). Evaluating teaching effectiveness and teaching improvement: A language for institutional policies and faculty development practices. International Journal of Academic Development, 7(1), 7-17.

Michavila, F. \& Zamorano, S. (2008). Panorama de los Sistemas de Garantía de Calidad en Europa: una visión trasnacional de la acreditación [Ejemplar especial]. Revista de Educación, 1, 235-263.

Ministerio de Educación, Cultura y Deporte. (2003). La integración del sistema universitario español en el Espacio Europeo de Enseñanza Superior. DocumentoMarco. Available at http://www.uam.es/europea/ documentomarco.pdf

Ministerio de Educación, Cultura y Deporte. (2006). Guidelines for the development of Academic Degrees and Masters Degree. Working Paper.

Muñoz, J. M. (2009). Los sistemas de garantía de calidad. Una directriz europea. Revista Fuentes, 9, 118-150.

Neave, G. (2003). The Bologna Declaration: Some of the historic dilemmas posed by the reconstruction of the community in Europe's systems of higher education. Educational Policy, 17(1), 141-164.

O’Donovan, B., Price, M. \& Rust, C. (2004). Know what I mean? Enhancing student understanding 
of assessment standards and criteria. Teaching in Higher Education, 9(3), 325-335.

Pill, A. (2005). Models of professional development in the education and practice of new teachers in Higher Education. Teaching in Higher Education, 10(2), 175-188.

Pozo-Muñoz, C., Giménez, M. L. \& Bretones, B. (2009). La evaluación de la calidad docente en el nuevo marco del EEES. Un estudio sobre la encuesta de opinión del Programa Docentia-Andalucía. Educación XXI, 11, 43-64.

Red Iberoamericana para la Acreditación de la Calidad de la Educación Superior. (2007). Proyecto para el apoyo en el desarrollo del Aseguramiento de Calidad Interna de las agencias de evaluación. Madrid: ANECA.

Red Española de Agencias de Calidad Universitaria. (2010). Recommendations for monitoring of official titles. Working Paper.

Rosa, M. J., Tavares, D. \& Amaral, A. (2006). Institutional consequences of quality assessment. Quality in Higher Education, 12(2), 145-159.

Spain, Boletín Oficial del Estado. (2007). Official Gazette, No. 260, October 30, 2007. Royal Decree 1393/2007 of 29 October 2007 establishing the management of university officials.

Spain, Boletín Oficial del Estado. (2010). Official Gazette, No. 161, July 3, 2010. Royal Decree 861/2010 of 2 July, amending the Royal Decree 1393/2007 of 29 October, establishing the management of university officials.

Støren, L. A. \& Amodt, P. O. (2010). The quality of Higher Education and employability of graduates. Quality in Higher Education, 16(3), 297-313.
Rentería-Pérez, E. \& Malvezzi, S. (2008). Empleabilidad, cambios y exigencias psicosociales en el trabajo. Universitas Psychologica, 7(2), 319-334.

Roxa, T. \& Martensson, K. (2008). Strategic educational development: A national Swedish initiative to support change in higher education. Higher Education Research $\mathcal{E}$ Development, 27(2), 155-168.

Rozsnyai, C. (2010). The quality volution. Quality in Higher Education, 16(1), 77-79.

Tandberg, D. (2010). Interest groups and governmental institutions: The politics of state funding of public higher education. Educational Policy, 24(5), 735-778.

University of Almería. (2009). Practice guidelines and performance standards units quality assurance degrees and master (UGCT/UGCM). Quality Unit. Vice President Planning, Quality and Relations with Society. Available at http://cms.ual.es/idc/groups/ public/@serv/@ucalidad/documents/documento/ unidad_calidad.pdf

University of Almería. (2010). Documentation of the quality assurance systems for parts of the University of Almería. Procedures and tools. Available at http:// cms.ual.es/UAL/universidad/serviciosgenerales/ ucalidad/documentacion/index.htm

Yinger, R. J. \& Hendriks-Lee, M. S. (2000). The language of standards and teacher education reform. Educational Policy, 14(1), 94-106.

Woodhouse, D. (2006). The quality of transnational education: A provider view. Quality in Higher Education, 12(3), 277-281. 